\title{
The judiciary - as a main guarantee of protection of the right of ownership
}

\author{
Khaji-Murad ISAKOV ${ }^{1}$ \\ High School Judges with the Supreme Judicial Council of the Republic of Uzbekistan
}

\begin{tabular}{l} 
ARTICLE INFO \\
\hline Article history: \\
Received October 2021 \\
Received in revised form \\
15 October 2021 \\
Accepted 15 November 2021 \\
Available online \\
25 December 2021 \\
\hline Keywords: \\
human rights and freedoms, \\
property, \\
right of ownership, \\
judiciary, \\
independence of judges, \\
Civil Code of the Republic of \\
Uzbekistan, \\
Plenum of the Supreme \\
Court of the Republic of \\
Uzbekistan, \\
Constitution.
\end{tabular}

\section{ARTICLE INFO}

\section{Article history:}

15 October 2021

Accepted 15 November 2021

Available online

Keywords:

human rights and freedoms,

roperty,

judiciary,

Civil Code of the Republic of

Constitution.

\section{ABSTRACT}

The right of ownership is recognized and protected by law in the Republic of Uzbekistan. Generally recognized principles, property rights, and freedom of contract are not strictly recognized. Which presuppose equality, autonomy of will and property independence of participants in civil law relations. Arbitrary interference in private affairs is not allowed. The freedom of ownership, use and disposal of property is conditioned, including the ability to alienate one's property into the ownership of other persons. Have their right to transfer property rights to someone, while remaining the owner, as well as their ownership rights, and the possibility of the right to use and dispose of.

This article analyzes the concept and genesis of the origin of property rights, and also substantiates the importance of protecting this right by the judicial power of any state. The author has studied the constitutional foundations, regulatory and legal mechanisms for ensuring the protection of property rights by the court. According to the results of the analysis, relevant conclusions were drawn and proposals were developed.

2181-1415/C) 2021 in Science LLC.

DOI: https://doi.org/10.47689/2181-1415-vol2-iss11/S-pp147-155

This is an open access article under the Attribution 4.0 International (CC BY 4.0) license (https://creativecommons.org/licenses/by/4.0/deed.ru)

\section{Sud hokimiyati mulk huquqini himoya qilishning asosiy kafolati sifatida}

\author{
Калит сўзлар: \\ inson huquq va erkinliklari, \\ mulk, \\ mulk huquqi,
}

\begin{abstract}
АННОТАЦИЯ
O'zbekiston Respublikasida mulk huquqi qonun bilan tartibga solinib himoya qilinadi. Umum e'tirof etilgan tamoyillar, mulk huquqi, shartnoma erkinligi daxlsiz deb tan olinadi. Bu fuqarolik-
\end{abstract}

\footnotetext{
$1 \mathrm{PhD}$ in Law, High School Judges with the Supreme Judicial Council of the Republic of Uzbekistan. Tashkent,
} Uzbekistan. 
sud hokimiyati, sudyalarning mustaqilligi, O'zbekiston

Respublikasining Fuqarolik kodeksi,

O'zbekiston Respublikasi

Oliy sudi Plenumi,

Konstitutsiya huquqiy munosabatlar ishtirokchilarining tengligi, irodasining mustaqilligi va mulkiy mustaqilligini nazarda tutadi. Shaxsiy ishlarga o'zboshimchalik bilan aralashishga yo'l qo'yilmaydi. Mulkga egalik qilish, undan foydalanish va uni tasarruf etish erkinligi, shu jumladan o'z mulkini boshqa shaxslarning mulkiga o'tkazish imkoniyati nazarda tutilgan. $\mathrm{O}^{\prime} \mathrm{z}$ huquqiga ega bo'lish, mulk huquqini birovga o'tkazish, mulkdor bo'lib qolgan, shuningdek, ularning egalik huquqi, foydalanish va tasarruf etish huquqi.

Ushbu maqolada mulk huquqining kelib chiqishi tushunchasi va genezisi tahlil qilinadi va har qanday davlatning sud organlari tomonidan ushbu huquqni himoya qilish muhimligi asoslantirilgan. Muallif konstitutsiyaviy asoslarni, sud tomonidan mulk huquqlarini himoya qilishni ta'minlashning normativ-huquqiy mexanizmlarini o'rgangan. Tahlil natijalari asosida tegishli xulosalar chiqarilib, takliflar ishlab chiqildi.

\section{Судебная власть - гарантия обеспечения и защиты права собственности}

\footnotetext{
Ключевые слова:

права и свободы человека, собственность,

право собственности, судебная власть, независимость судей, Гражданский кодекс Республики Узбекистан, Пленум Верховного суда Республики Узбекистан, Конституция.
}

\section{АННОТАЦИЯ}

Право собственности, в Республике Узбекистан признается и охраняется Законом. Неприкоснительно признаются, общепризнанные принципы, право собственности, свободы договора. Которые, предполагают равенство, автономию воли и имущественную самостоятельность участников гражданско-правовых отношений. Не допускается, произвольное вмешательство в частные дела. Обусловливается, свобода владения, пользования и распоряжения имуществом, включая возможность отчуждать свое имущество в собственность другим лицам. Иметь, свое право, передавать кому-либо имущественные права, оставаясь собственником, а также их права владения, и возможности права пользования и распоряжения.

В данной статье проанализированы понятие и генезис происхождения права собственности, также обоснована, важность защиты этого права судебной властью любого государства. Автором изучены конституционные основы, нормативно-правовые механизмы обеспечения защиты судом права собственности. По результатам анализа сделаны соответствующие выводы и разработаны предложения.

\section{INTRODUCTION}

The problem of protection of fundamental human rights and freedoms is one of the universal ones - these are values, which are subject to priority protection in all spheres of public and state life. In the general scale of humanitarian values, human rights occupy a 
central place in the same level as a value of a person himself. In any democratic system, the rights and freedoms of citizens, as well as their legal duties, constitute the most important social, political and legal institution, which serves as an indicator of maturity of a society.

One of basic human rights is the right to own, use and dispose of property. Property is untouchable and sacred. This postulate, which previously caused a lot of controversies, is now universally recognized in the heyday of product-money relations.

It should be noted that the right of ownership is quite vulnerable, both on the part of participants in civil law relations, and also on the part of public authorities and administration. A crucial role in ensuring adequate and effective protection of property rights is exercised by courts. The entire judicial system shall ensure the correct enforcement of legal acts governing property relations. And the task of any state, including the Republic of Uzbekistan, is to create an effective and modern judicial system, which is able to solve problems of ensuring the rights and freedoms of citizens.

Therefore, reforming the judicial system is one of the most important directions of state policy. This issue has always been and continues to receive special attention. Thus, the Action Strategy for five priority areas of development of the Republic of Uzbekistan in 2017-2021, which is one of the main directions of further development, provides for the modernization of the judicial system [1].

\section{METHODOLOGY}

In solving the tasks set in this article, general scientific and special methods of scientific knowledge were used: system, specific-sociological, comparative-legal, analytical, quantitative analysis (content analysis), logical-legal, etc.

The analysis of the norms of the legislation of the Republic of Uzbekistan and a number of foreign countries, some international acts, doctrinal works, scientific articles in the field of criminal law and criminology was used as an empirical basis.

Together, all these methods made it possible to ensure the reliability and validity of the research results in a scientific article to a certain extent

\section{Results of the study of determinants}

As, the President of the Republic of Uzbekistan, Shavkat Mirziyoyev, noted in his festive congratulations on Constitution Day: "Deep reforms are being carried out in accordance with an important constitutional provision - ensuring human rights and interests in all spheres, especially in judicial and legal" [2].

Indeed, an independent and effective judiciary is a guarantee for ensuring and protecting human rights. This is the most important condition for effective compliance with the law.

On December 7, 2020, the President signed the Decree "On Measures to ensure the true independence of judges and improve the efficiency of Anti-corruption actions in the judicial system" [3]. The document defined main directions of state policy in these areas.

In the context of the implementation of the state's policy of improving the activities of courts in the field of protecting rights and interests of private and legal persons, special importance is attached to judicial protection of property rights.

Art. 19 of the Constitution of the Republic of Uzbekistan provides: "the rights and freedoms of citizens enshrined in the Constitution are inviolable, and no one can be arbitrarily deprived of it without a court order" [4]. Additionally, Art. 10 of the Civil Code of the Republic of Uzbekistan defines: "Protection of civil rights is carried out in accordance 
with the jurisdiction of cases established by procedural legislation or an agreement, a court or an arbitration" [5]. This provision applies to the protection of ownership as well. The main and most effective methods of protection are those, which provide for judicial protection in response to a claim submitted to courts on the matter of violation of ownership rights.

The protection of ownership title is carried out on the basis of civil law norms that: establish the ownership of material goods to the subjects of civil legal relations; determine the degree of their property isolation; provide owners with the conditions for the exercise of their rights within certain limits; establish unfavorable consequences for persons, who violated the rights of owners. Protection of property rights is tied with state regulation of the distribution of property between subjects of civil law, as well as with state permission to have and dispose of property within certain limits.

An example of the distinct attention of the judiciary to the protection of property rights is seen in a number of Resolutions of the Plenum of the Supreme Economic Court and the Supreme Court of the Republic. The most significant is the Resolution of the Plenum of the Supreme Economic Court of the Republic of Uzbekistan (as amended on May 19,2018 No. 17) "On some issues of the application of legislation by economic courts when considering cases on the recognition of ownership", which provides:

"When considering cases on the matter of recognition of property rights, the courts must strictly follow the Constitution of the Republic of Uzbekistan, the Civil Code of the Republic of Uzbekistan (hereinafter referred to as the CC), the Economic Procedural Code of the Republic of Uzbekistan (hereinafter referred to as the EPC), the Law of the Republic of Uzbekistan "On Property in the Republic of Uzbekistan", as well as other regulatory legal acts" [6].

According to Article 54 of the Constitution and Article 164 of the Civil Code, the right of ownership is the right of a person to own, use and dispose of the property belonging to him at his own discretion and in his own interests, and also demand the elimination of any violations of his property rights.

In accordance with Article 182 of the Civil Code, the grounds for acquiring ownership rights are: labor activity; entrepreneurial and other economic activities related to the use of property, including the creation, increment, acquisition of property through transactions; privatization of state property; inheritance; acquisitive prescription; other grounds, not contradicting to the legislation.

In the second paragraph of the first part of Article 11 of the Civil Code, it is provided that the protection of civil rights is carried out by recognition of that right. According to paragraph 6 of the first part of Article 26 of the EPC, economic courts resolve disputes over the recognition of property rights.

The Plenum clarifies the procedural provisions:

"It is necessary to draw the attention of the economic courts to the fact that the cases on the recognition of ownership and on the establishment of facts of legal significance are procedurally different from each other.

If there is a dispute in cases on the recognition of ownership, they are considered on the basis of the claim and with presence of the parties (the plaintiff and the defendant), as well as, if necessary, third parties are involved.

Cases on the establishment of facts of legal significance are initiated on the basis of applications for the establishment, change and termination of the rights of citizens and organizations in the economic sphere. Since there is no dispute in these cases, they are 
considered with the participation of the applicant, and if necessary, with involvement of interested parties. In such cases, there is no respondent.

If a claim for the recognition of ownership is submitted to the court, but its content implies the requirement to establish a fact of legal significance, then the court refuses to satisfy such a claim".

Analysis of the main provisions of the Resolution of the Plenum of the Supreme Economic Court of the Republic of Uzbekistan and similar Resolutions of the Plenums of the Supreme Court of the Republic of Uzbekistan demonstrate clearly that, ultimately, judicial practice have become the cause of so-called absolute force for the recognition of ownership: a person who did not participate in the consideration of the case for the recognition of ownership cannot bring a claim on invalidation of a registered property right without first challenging the court decision. The basis for refusal to satisfy claims for recognition of ownership in such cases is provided by Article 15 of the EPC RUz, which establishes that judicial acts are binding on public authorities, self-government bodies, other bodies, organizations, officials and citizens, and subject to execution throughout the territory of the Republic of Uzbekistan.

The resulting law enforcement model puts the law in actual and legal dependence on the decisions made by the court: the rule of law is valid only if the court makes the appropriate decision. This is followed by the law being implemented through the adoption of a court decision, which launches the enforcement mechanism. This situation is partly the result of the absolutization of a court decision as a main instrument in the law enforcement mechanism, when a court act is considered as the main legal fact of substantive law, on the basis of which subjective rights and obligations are terminated. The priority is given to a decision of courts, which essentially determine the life of the rule of law and its implementation; and, interestingly, the force of the law is placed under the condition of the validity of the court decision.

In addition, the role of a court decision in the mechanism for the implementation of subjective civil law for protection is worth pointing out. If we consider the action of the mechanism for the protection of rights completed only after the real and actual elimination of violations of the law, then, the restoration of a violated subjective civil right by positive decision of a court is not the indicator of full elimination. The indicator is proper execution of that court decision.

However, here, the main emphasis should be made not only on the point of execution of the court decision, but on real execution of the requirement of a legislation expressed in the court decision.

It should be born in mind that the absolutization of a court decision in the recognition of property rights can be used by unscrupulous participants in the process through the use of various schemes of abuse of procedural rights. K.I. Sklovsky describes a situation in which two persons, who do not have any real rights to the allegedly disputed property, start a trial, the result of which is a court decision in favor of one of the parties [7]. For a real owner of the property, the implementation of such a scheme can lead to extremely unfavorable consequences. In the described situation, the court decision becomes a legal fact, on the basis of which the plaintiff in bad faith becomes the title holder, abusing the norms of Chapter 15 of the Civil Code of the Republic of Uzbekistan, containing an exhaustive list of grounds for acquiring ownership rights. 
The Constitution and laws of Uzbekistan determine that the issue of restriction or deprivation of property rights is resolved in the manner prescribed by laws, that is, the regulatory legal acts of the Oliy Majlis of the Republic of Uzbekistan.

Thus, the Constitution of the Republic of Uzbekistan states:

"None of the provisions of this Constitution can be interpreted to the detriment of the rights and interests of the Republic of Uzbekistan. No law or other normative legal act can contradict the norms and principles of the Constitution" (Article 16).

"The rights and freedoms of citizens enshrined in the Constitution and laws are inviolable, and no one has the right to deprive or restrict them without a court decision" (Article 19).

"The basis of the economy of Uzbekistan, aimed at the development of market relations, is property in its various forms. The state guarantees freedom of economic activity, entrepreneurship and labor taking into account the priority of consumer rights, equality and legal protection of all forms of ownership" (Article 53).

Article 166 of the Civil Code unambiguously and clearly defines: "Property is inviolable and protected by the Law." Seizure of property from the owner, as well as limitation of his powers is allowed only in cases stipulated by legislative acts".

The Housing Code of the Republic of Uzbekistan in Art. 11 provides:

"Residential buildings, apartments that are in private ownership cannot be seized, the owner cannot be deprived of the right of ownership of a residential building, apartment, except in cases established by law. Forced seizure of residential premises is allowed only on the basis of a court decision in cases and in the manner prescribed by law" [8].

Also, the Law "On Property in the Republic of Uzbekistan" defines:

"Private property, along with other forms of property, is inviolable and protected by the state. The owner may be deprived of it only in cases and in the manner prescribed by the law". (Part 2 of Article 7) [9].

The Law "On Protection of Private Property and Guarantees of Owners' Rights", in article 2 provides: "The owner may be deprived of his property only in cases and in the manner prescribed by the law".

Article 17 adds: "Property in private ownership is not subject to nationalization, confiscation and requisition, except in cases stipulated by law." This provision is followed by Art. 23 of the Law "On guarantees of freedom of entrepreneurial activity":

"The seizure of property, the termination of other property rights of a business entity, as well as their limitation are not allowed, with the exception of cases provided by law" [10].

\section{DISCUSSION OF CONCLUSIONS AND PROPOSALS}

Analysis of the above-mentioned Laws demonstrate clearly that property rights cannot be limited and no one can be deprived of property except by a court decision. (Article 19 of the Constitution) Decisions made by other bodies will be contrary to the Constitution and Laws, which means that the body initiating the seizure of property must approach a court in any case.

The state takes vigorous measures to prevent violations in the field of ownership protection. In 2018-2020, a number of important regulations were adopted, which were aimed at strengthening the protection of ownership rights. This is how the Law of the 
Republic of Uzbekistan "On Amendments and additions to some legislative acts of the Republic of Uzbekistan, in connection with further strengthening of guarantees of the rights and legitimate interests of owners", dated December 24, 2020 No. 656, introduced amendments to the Land Code and to the Law of the Republic of Uzbekistan "On the Protection of Private Property and Guarantees of Owners' Rights" in order to improve the inviolability of private property [11].

The powers to seize land for state and public needs, as well as the implementation of investment projects, were transferred to the Jokargy Kenes of the Republic of Karakalpakstan and the Kengashes of people's deputies of the regions and the city of Tashkent.

Additionally, amendments have been made to the Law of the Republic of Uzbekistan "On local bodies of state authority" and to Articles 5, 6, 7, 36-38 of the Land Code, providing for the exclusion of the right to seize land from khokims of districts, cities, regions [12].

In addition, the right of ownership or the right to permanent or temporary use of all or part of a land, as well as to lease a land, can be terminated by the decision of the khokims of districts, cities, regions or by the decision of the Cabinet of Ministers of the Republic of Uzbekistan only in the following cases:

1) voluntary refusal from the land;

2) expiration of the period for which the land was provided;

3) liquidation of a legal entity;

4) termination of labor relations in connection with which the land was provided, unless otherwise defined by law.

In other cases, the right of ownership or the right of permanent or temporary use of the entire land or its part, as well as lease of the land, can be terminated only by a court decision on the basis of a claim by the body that provided that land.

However, before the adoption of this act, there were cases when a subject deprived of the right of ownership had to refer to a court after a state body (khokimiyat, etc.) made a decision to seize property in illegal matter outside the competences given to it by the Constitution and the above-mentioned laws. This was a consequence of the fact that indication in a number of laws and regulations that decisions on limiting or deprivation of ownership can be adopted by state bodies on the basis of legislation or acts of legislation, in fact, transferred exclusive competence to the executive branch of government.

In accordance with the order of the President of the Republic of Uzbekistan from August 3, 2019 No. R-5491, the seizure of land within the framework of the effective implementation of state programs and investment projects is allowed only in compliance with the established rules aimed at ensuring and protecting the rights of persons whose land is being seized. These documents contain a list of grounds and the procedure for the seizure of a land for particular purposes [13].

In this regard, additions were introduced to the Article 19 of the Law "On protection of private property and guarantees of the owners' rights", providing that a decision of the Council of Ministers of the Republic of Karakalpakstan, khokimiyats of regions and the city of Tashkent or a district (city) on the demolition of immovable property located on the seized land is made only if there is a positive conclusion from the justice authorities. An agreement on compensation for losses in connection with the seizure of a land, concluded between the initiator of the seizure of the land and the owner of the immovable property located on the seized land shall be duly notarized. The decision on the demolition of the 
immovable property is allowed only after a compensation of losses to the owner of an immovable property located on the seized land was fully made, including lost profits and other expenses established in the agreement, and in the event of a dispute - in a court decision.

Demolition of real estate objects owned by individuals and legal entities of a seized land is allowed only after residential and non-residential buildings, production and other buildings and structures are fully emptied. Additionally, full reimbursement of the market value of immovable property located on the seized land shall be made including expenses related to relocation, including the temporary receipt of another immovable property, lost profits of individuals and legal entities, and other expenses and losses stipulated by law.

Losses caused to individuals and legal entities as a result of the issuance of an illegal administrative act by a state body (official) are subject to compensation by the state, in the first place, at the expense of extra-budgetary funds of the relevant authorities with subsequent recovery from the guilty person in a recourse manner.

It is important to note that property can be forcibly seized for various reasons, for example, for public needs or as part of the owner's repayment of his contractual, tort or administrative obligations (these are the so-called default obligations).

The fact that encroachment on someone else's property is not fair is axiomatic. The principle of prohibiting encroachment on someone else's property should be ensured, including when an object of private property is seized for public needs. National instruments and mechanisms should be brought in line with international standards

The implementation of the radical economic reform being carried out in the Republic of Uzbekistan, aimed at creating a market economy in the country, fundamentally new economic relations, is impossible without ensuring effective protection of property rights. This goal, to a greater or lesser extent, is devoted to the norms of practically all branches of legislation, and, first of all, to civil law. Civil law protects property rights in several ways, a significant place among which is the property-legal methods of protecting property rights. However, despite the well-known tradition of this institution, the system of rules of this institution that has been worked out for centuries, it nevertheless harbors many problems of both theoretical and purely practical nature.

It is clear that all the issues considered in this paper require their resolution at the level of legislation. Most of them are of more scientific rather than practical interest. However, no less important in law enforcement is their doctrinal interpretation, which makes it possible, in the absence of legislative regulation of a specific issue, to use the ways of resolving it developed by science as an argumentation basis.

\section{REFERENCES:}

1. Strategy of action of the Republic of Uzbekistan in five priority directions in 2017-2021 years. Appendix to Presidential Decree from 7 of February 2017, №PD-4947.

2. Festive Congratulations of President Sh. Mirziyoev on Constitution day on 7 th of December 2020.

3. Presidential Decree "On Measures to ensure the true independence of judges and improve the efficiency of Anti-corruption actions in the judicial system" from December 7 , 2020.

4. Constitution of the Republic of Uzbekistan

5. Civil Code of the Republic of Uzbekistan 
6. Resolution of the Plenum of the Supreme Economic Court of the Republic of Uzbekistan (as amended on May 19, 2018 No. 17) "On some issues of the application of legislation by economic courts when considering cases on the recognition of ownership"

7. Sklovskiy K.I. "Ob usloviyah predyavleniya iska o priznanii prava sobstvennosti" // Vestnik, 2008, №1, page 38.

8. The Housing Code of the Republic of Uzbekistan.

9. Law "On Property in the Republic of Uzbekistan".

10. Law "On Protection of Private Property and Guarantees of Owners' Rights".

11. Law of the Republic of Uzbekistan "On Amendments and additions to some legislative acts of the Republic of Uzbekistan, in connection with further strengthening of guarantees of the rights and legitimate interests of owners" from December 24, 2020.

12. Law of the Republic of Uzbekistan "On the Protection of Private Property and Guarantees of Owners' Rights".

13. Law of the Republic of Uzbekistan "On local bodies of state authority".

14. Order of the President of the Republic of Uzbekistan from August 3, 2019. No. R-5491. 